\title{
PENINGKATAN PENGETAHUAN ANAK DAN PERAN ORANG TUA SERTA GURU SEKOLAH DALAM MEMPERSIAPKAN ANAK KEMBALI BERSEKOLAH SELAMA PANDEMI
}

\author{
Gusgus Ghraha Ramdhanie ${ }^{1 *}$, Bambang Aditya Nugraha², Ema Arum \\ Rukmasari $^{3}$
}

${ }^{1-4}$ Fakultas Keperawatan Universitas Padjadjaran

Email Korespondensi: gusgus.ghraha.ramdhanie@unpad.ac.id

\begin{abstract}
ABSTRAK
Pembukaan kembali sekolah pada masa pandemi bagi anak beresiko munculnya masalah baru terkait penularan Covid-19. Kembalinya metode belajar menjadi luring (offline), anak akan kembali berkumpul di sekolah, hal tersebut dapat berujung pada peningkatan resiko penularan infeksi virus Covid-19 pada anak. Pembukaan sekolah harus dilaksanakan dengan hati-hati agar sekolah tidak menjadi cluster baru penyebaran covid 19. Pembukaan kembali sekolah telah menciptakan tugas baru bagi orang tua untuk mengedukasi dan mempersiapkan anak kembali ke sekolah di masa pandemi, berkaitan dengan penerapan protokol kesehatan. Dalam upaya meningkatkan pengetahuan dan pemahaman mengenai pentingnya protokol kesehatan dan persiapan anak bersekolah, maka yang dapat dilakukan adalah pendidikan kesehatan baik pada anak, orang tua maupun guru sekolah. Berdasarkan hasil evaluasi sebelum dan sesudah diberikan penyuluhan, menunjukkan terdapat perbedaan pengetahuan sebelum dan sesudah pendidikan kesehatan, nilai mean pretest $73.48 \%$ dan nilai post test $84.33 \%$, sedangkan pvalue $0,002(\mathrm{pv}<0,05)$. Anak, orang tua dan guru paham terkait protokol kesehatan selama anak bersekolah, kemudian dari respon yang diamati, mereka sangat menyukai pendidikan kesehatan ini dengan menuliskan komentar positif.
\end{abstract}

Kata kunci: covid-19, protokol kesehatan, anak bersekolah

\begin{abstract}
The reopening of schools during the pandemic risks the emergence of new problems related to the transmission of Covid-19 in schools. With the offline learning method, children will gather at school, this can lead to an increased risk of transmitting Covid-19 to children. The opening of schools must be carried out carefully so that schools do not become new clusters of the spread of covid 19. The reopening of schools has created a new task for parents to educate and prepare children to return to school during the pandemic, related to the implementation of health protocols. In an effort to increase knowledge and understanding of the importance of health protocols for preparing children for school, what can be done is health education for children, parents and school teachers. Based on the results of the evaluation, before and after being given counseling, there were differences in knowledge, the mean pretest value is $73.48 \%$ and the posttest value is $84.33 \%$, while the $p$-value is 0.002 ( $p v<0.05)$.
\end{abstract}


Children, teachers and parents understand about health protocols while children are in school, then from the observed response they really like this Health education by writing positive comments.

Keyword : covid-19, health protocol, children back to school

\section{PENDAHULUAN}

Satuan Tugas (Satgas) Penanganan Covid-19 mencatat jumlah kasus Covid-19 nasional pada anak usia sekolah per Desember 2020 dominan di jenjang sekolah dasar atau SD. Secara keseluruhan, kasus positif Covid-19 pada anak usia sekolah mencapai 8,87 persen dari total kasus virus Corona nasional. Berdasarkan data per Desember 2020, Satgas Penanganan Covid-19 melaporkan adanya 59.776 anak usia sekolah yang terinfeksi Covid-19. Pada anak usia sekolah SMP (13-15 tahun) dilaporkan ada 11.239 kasus positif Covid-19 atau sekitar 18,8 persen dari keseluruhan kasus nasional. Adapun, peningkatan kasus positif Covid-19 pada anak usia sekolah mencapai 59,72 persen dalam kurun waktu sebulan. Untuk meminimalisir penularan COVID19 pada satuan pendidikan, pemerintah mengeluarkan kebijakan belajar di rumah melalui metode daring (Kristiyanto, Chandra, Hanjaya, Hakim, \& Nurputra, 2019; Dewi, 2020; UNICEF, 2020).

Pandemi Covid-19 menyebabkan penutupan sekolah di Indonesia. Hal tersebut berdampak negatif ke beberapa aspek seperti pendidikan dan perkembangan anak, psikologis anak dan ekonomi keluarga. Pada sudut pandang perkembangan anak, tidak bisa dipungkiri bahwa sekolah merupakan institusi yang berpengaruh besar dalam menstimulasi dan memfasilitasi perkembangan anak, sehingga penutupan sekolah akan beresiko mengurangi kesempatan anak untuk berkembang. Mereka tidak akan mengerti sepenuhnya tentang apa yang sedang terjadi, sehingga berujung kepada perasaan tidak nyaman dan frustasi dengan keadaan pandemi ini. Penutupan sekolah mengharuskan anak untuk bersekolah dengan metode daring (online). Metode sekolah tersebut menyebabkan orangtua harus menyiapkan dana lebih untuk membeli gawai yang digunakan dalam menunjang pembelajaran anaknya. Akhirnya penutupan sekolah pun berdampak pada aspek ekonomi keluarga (Kusumanita, 2020 ; UNICEF, 2020).

Menteri Pendidikan dan Kebudayaan (Mendikbud) Nadiem Makarim menegaskan, bahwa pembelajaran tatap muka (PTM) terbatas akan mulai dilakukan pada bulan Maret 2021. Surat keputusan bersama (SKB) empat menteri mengenai Panduan Penyelenggaraan Pembelajaran di Masa Pandemi Covid-19 yang diumumkan pada 30 Maret 2021 sudah mulai berlaku. Panduan tersebut berisikan pembahasan terkait pembelajaran tatap muka dapat dilakukan secara bertahap berdasarkan jenjang pendidikan dengan menerapkan dua fase, yaitu masa transisi selama 2 bulan dan jika tidak ditemukan kasus COVID-19 baru, maka ditindaklanjuti dengan fase kebiasaan baru atau tatanan hidup baru pandemi (Kemdikbud, 2021).

Presiden RI Ir. Joko Widodo dalam pidato resminya menyatakan bahwa Kehidupan sudah pasti berubah dan untuk mengatasi risiko wabah yang disebut sebagai New Normal atau tatanan kehidupan baru, yaitu suatu tindakan atau perilaku yang dilakukan oleh masyarakat dan semua institusi yang ada di wilayah tersebut. Bila hal ini tersebut tidak dilakukan, akan menimbulkan risiko penularan. Adaptasi Kebiasaan Baru (AKB) adalah istilah yang digunakan pemerintah untuk menggantikan istilah "New Normal". 
Tujuan dari AKB adalah agar masyarakat tetap bekerja, belajar, dan beraktivitas dengan produktif dan aman dari virus Corona di masa pandemic Covid-19, sehingga pembukaan sekolah Kembali bagi anak sangat memungkikan dilakukan (Pintek, 2020).

Berdasarkan penelitian yang telah dilakukan oleh Dewi (2020) didapatkan hasil bahwa pengetahuan mengenai pencegahan penularan COVID-19 seluruh anak tergolong rendah. Oleh karena itu, pemahaman mengenai protokol kesehatan pada anak usia sekolah sangatlah penting terlebih dengan pembukaan sekolah Kembali bagi anak. Salah satu hal yang dapat dilakukan untuk melindungi diri dari penularan Covid-19 pada saat anak beraktifitas di sekolah adalah menerapkan protokol kesehatan, seperti melaksanakan 3M (mencuci tangan, menggunakan masker dan menjaga jarak) secara disiplin. Selain itu, pentingnya peran orang tua di rumah untuk melaksanakan $3 \mathrm{M}$ juga penting dan diharapkan dengan memberikan pendidikan kesehatan mengenai Covid-19 sebelum kembali ke sekolah, anak dapat memahami serta menerapkan protokol kesehatan yang ada.

\section{MASALAH}

Pembukaan kembali sekolah pada masa pandemi bagi anak beresiko munculnya masalah baru terkait penularan Covid-19. Kembalinya metode belajar menjadi luring (offline), anak akan kembali berkumpul di sekolah, hal tersebut dapat berujung pada peningkatan resiko penularan infeksi virus Covid-19 pada anak. Dengan mempertimbangkan peningkatan angka penularan, pembukaan sekolah harus dilaksanakan dengan hati-hati agar sekolah tidak menjadi cluster penyebaran covid 19. Sekolah harus menjadi salah satu pilar dalam mengidentifikasi dan menanggulangi resiko penyebaran penyakit, dan untuk mempersiapkan regulasi pembukaan kembali sekolah. Kerjasama yang baik di antara guru dan orang tua sangat penting untuk mencegah transmisi penyakit lebih lanjut melalui pengembangan protokol kesehatan saat sekolah sudah kembali dibuka.

Adanya kebijakan pembukaan kembali fasilitas pendidikan atau sekolah telah menciptakan tugas baru bagi orang tua untuk mengedukasi dan mempersiapkan sang anak kembali ke sekolah di masa pandemi, salah satunya berkaitan dengan penerapan protokol kesehatan pada anak di sekolah. Protokol kesehatan dibentuk agar masyarakat tetap dapat melakukan aktivitas secara aman, tidak membahayakan keamanan atau kesehatan orang lain, dan produktif dengan bekerja, belajar, dan beraktivitas di masa adaptasi kebiasaan baru, termasuk anak yang akan kembali belajar di sekolah. Namun tingkat pengetahuan dan kesadaran orang tua dan guru untuk menerapkan protokol kesehatan pada anak masih rendah.

\section{METODE}

Dalam upaya meningkatkan pengetahuan dan pemahaman orang tua dan guru mengenai pentingnya protokol kesehatan dan hal-hal apa yang harus dipersiapkan saat anak belajar kembali ke sekolah, maka yang dapat dilakukan adalah pendidikan kesehatan baik pada anak, orang tua maupun guru di sekolah dengan tema Pendidikan Kesehatan "Ready for BTS (Back To School) During The Pandemic"

a. Tahap Persiapan

Tahap persiapan dari kegiatan pengabdian masyarakat untuk 
meningkatkan pengetahuan dan pemahaman anak, orang tua dan guru mengenai pentingnya protokol kesehatan dalam mempersiapkan kembali belajar di sekolah adalah mempersiapakan platform zoom meeting pro dengan jumlah partisipan lebih dari 100 dengan waktu unlimit dan pembuatan e-poster serta video edukasi.

b. Tahap pelaksanaan

Pendidikan Kesehatan "Ready for BTS (Back To School) During The Pandemic" adalah kegiatan pendidikan dan promosi kesehatan yang diselenggarakan oleh dosen dan mahasiswa Fakultas Keperawatan Universitas Padjadjaran. Kegiatan pendidikan dan promosi kesehatan ini dikemas dalam bentuk diskusi terbuka atau talkshow melalui platform zoom meeting, dimana peserta dan pemateri dapat saling bertukar pengetahuan mengenai pencegahan COVID-19 pada anak, dan mempersiapkan anak kembali ke sekolah dengan sehat di masa pandemi melalui program sekolah ramah anak.

c. Evaluasi

Sebelum pemberian materi dilakukan sesi pre-test guna mengetahui tingkat pengetahuan peserta terkait COVID-19 pada anak dan pencegahannya serta mengetahui kesiapan anak kembali ke sekolah dimasa pandemi. Selanjutnya dilakukan pemberian materi sesuai topik dan diakhiri dengan sesi tanya jawab dan post-test yang digunakan untuk mengukur indikator capaian keberhasilan dari promosi kesehatan Ready for BTS (Back To School) During The Pandemic.

\section{HASIL DAN PEMBAHASAN}

Pendidikan kesehatan ini dilaksanakan secara daring melalui aplikasi zoom meeting pada tanggal 19 Juni 2021 pukul 08.30-11.05 dengan jumlah responden 141 orang. Kegiatan ini dilakukan secara daring karena mengingat adanya aturan menjaga jarak, bekerja dan belajar dari rumah sehingga tidak memungkinkan untuk dilaksanakan secara luring. Jumlah peserta pendaftar tercatat 263 peserta, namun peserta yang hadir hanya 178 peserta tetapi hanya 141 peserta yang mengisis form presensi, pre test, dan juga post test. Hal ini terjadi karena peserta kami mengalami berbagai hambatan, seperti jaringan tidak stabil, sedang bekerja, sakit, maupun ujian sehingga tidak dapat menghadiri secara penuh kegiatan ini.
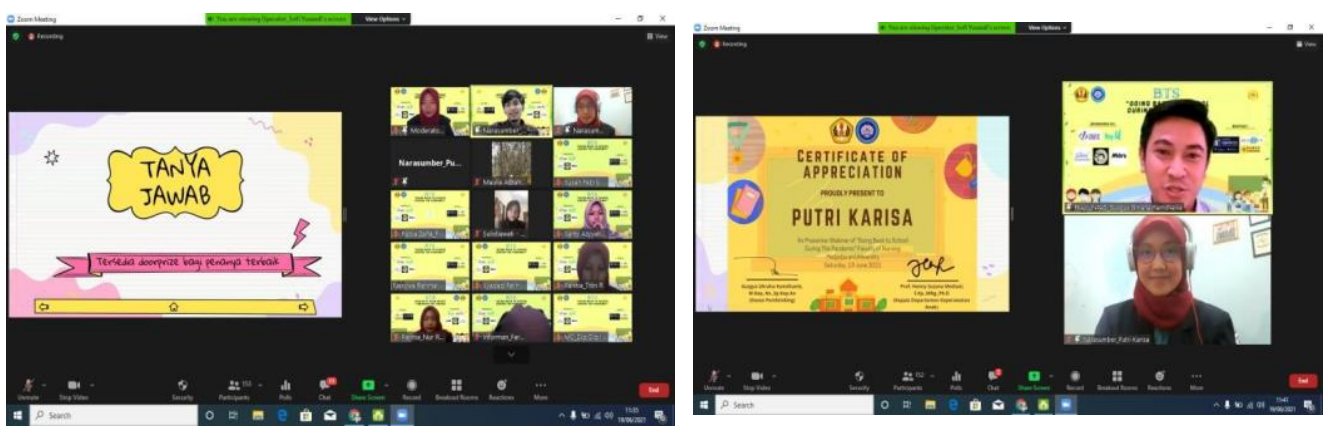

Gambar 1. Poto pelaksana kegiatan via zoom 

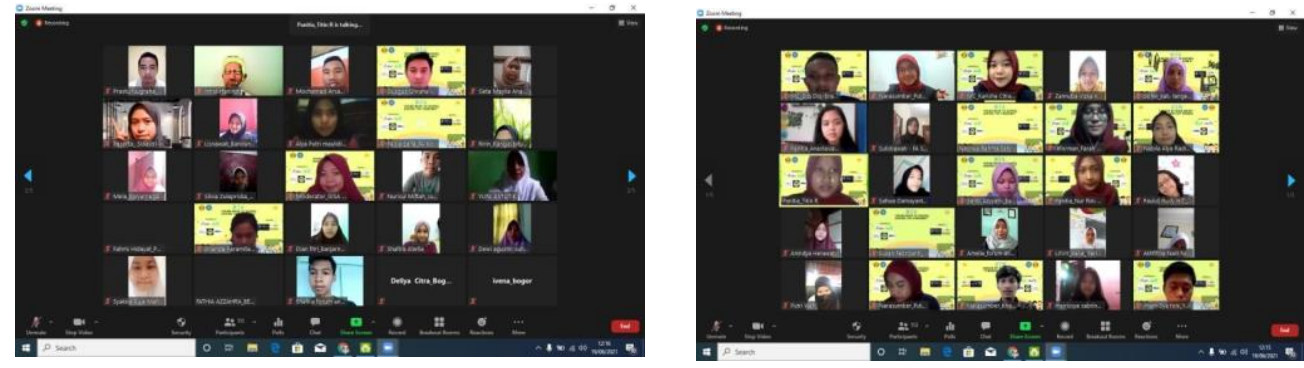

Gambar 2. Poto pelaksana kegiatan via zoom

Peserta berada dalam rentang usia 12-52 tahun. Karakteristik peserta yaitu siswa yang sedang menempuh pendidikan dibangku Sekolah Dasar (SD, Sekolah Menengah Pertama (SMP), dan Sekolah Menengah atas (SMA). Selain itu responden juga berasal dari masyarakat umum (sebagai keluarga) yang memiliki anggota keluarga dalam rentang usia anak, dan tenaga pendidik seperti Guru juga Kepala Sekolah.

Tabel 1. Perbedaan Rata-rata Pengetahuan Peserta Sebelum dan Setelah Pendidikan Kesehatan $(n=141)$

\begin{tabular}{|c|c|c|c|}
\hline Pengetahuan & Mean & SD & Sig 2-tailed \\
\hline Sebelum & 73.48 & 14.040 & \multirow[t]{3}{*}{0.002} \\
\hline Pendidikan Kesehatan & & & \\
\hline Setelah Pendidikan Kesehatan & 84.33 & 13.748 & \\
\hline
\end{tabular}

Pada tabel 1 didapatkan hasil bahwa nilai mean pretest/ sebelum dilakukan Pendidikan kesehatan adalah (73.48) dan post test/setelah Pendidikan kesehatan (84.33), sedangkan pvalue 0,002 <0,05, sehingga dapat disimpulkan bahwa ada perbedaan rata-rata antara hasil belajar yang berarti adanya pengaruh pemberian pendidikan kesehatan terhadap peningkatan pengetahuan peserta terhadap pencegahan COVID-19 pada anak. Pendidikan kesehatan secara konseptual merupakan upaya untuk mempengaruhi dan mengajak seseorang bahkan masyarakat agar melakukan perilaku hidup sehat (Notoatmojo, 2011). Pelaksanaan Pendidikan kesehatan akan optimal jika menggunakan media yang tepat (Kristiyanto, Chandra, Hanjaya, Hakim, \& Nurputra, 2019).Terdapat hal yang menarik dari pendidikan kesehatan yang telah dilakukan di ruang zoom meeting yaitu adanya antusias yang sangat besar serta penerimaan peserta dengan pendidikan kesehatan yang dilakukan. Pengemasan acara yang kami buat dengan pematerian semi formal dengan mengedepankan interaksi dengan anak dengan menggunakan bahasa sederhana dan kami mengundang pembicara aktivis anak dari forum anak nasional yang dilanjutkan dengan sharing session membuat peserta sangat antusian dengan kegiatan tersebut. Sehingga mereka mampu mengikuti kegiatan pendidikan kesehatan dengan penuh perhatian, mendengarkan secara aktif, dan interaksi dua arah yang diperlihatkan selama proses berlangsungnya pendidikan kesehatan. Hal menarik lainnya adalah jumlah penanya yang banyak sekali dan adanya beberapa peserta yang hadir dan menanyakan terus-menerus terkait kegiatan ini pada kami. Beberapa kali pemateri memberikan pertanyaan mengenai pendapat para peserta, tidak 
jarang mereka saling berebut untuk menjawab pertanyaan tersebut.

Berdasarkan pertanyaan yang diajukan banyak berkaitan tentang peran orang tua pada anak. Orang tua merasa bingung dengan kebijakan pemerintah dalam pembukaan kembali sekolah, sementara mereka harus mempersiapkan anak untuk kembali belajar di sekolah dan apa yang harus mereka siapkan. Menurut Kusumanita (2020) orang tua perlu memberikan edukasi kepada anakanak mengenai keadaan yang sedang terjadi saat ini. Dengan keadaan yang berubah membuat anak-anak tidak bisa bermain dengan bebas di luar rumah dapat menjadikan suatu stressor baru bagi anak. Orang tua harus memberikan pengertian dengan bahasa yang mudah dipahami mengenai kondisi sekarang sehingga anak-anak menjadi tau dan mau untuk mematuhi protokol kesehatan (Iftitah, 2020).

Pada tahap evaluasi menunjukkan hasil yang sangat baik, terdapat pengaruh pendidikan kesehatan yang diberikan terhadap pengetahuan peserta, kemudian dari respon yang diamati mereka sangat menyukai kegiatan ini dengan menuliskan komentar bahwa acara ini merupakan acara yang menarik, memiliki segudang manfaat bagi pengetahuan, dan juga peserta berharap akan diadakan kegiatan serupa dengan tema yang sama untuk kelompok populasi lainnya. Hal ini sesuai dengan pendapat Notoatmodjo (2011), proses belajar melalui Pendidikan kesehatan merupakan suatu proses terjadinya perubahan kemampuan pada subjek belajar dengan keluaran yang dapat diharapkan adalah kemampuan sebagai hasil dalam adanya perubahan perilaku dari sasaran didik.

\section{KESIMPULAN}

Berdasarkan hasil kegiatan pengabdian pada masyarakat ini dapat melalui penuluhan atau pendidikan kesehatan ini dapat disimpulkan

a. Pendidikan kesehatan efektif untuk meningkatkan pengetahuan anak, orang tua, dan tenaga pendidik terakait pencegahan COVID-19 pada anak.

b. Hasil analisis menunjukkan hasil yang baik terkait pengetahuan peserta sesudah diberikan pendidikan kesehatan, yang dapat menjadi acuan bagi anak, orang tua, maupun temaga pendidik untuk mencegah penularan virus COVID-19 dimasa adaptasi kebiasaan baru terutama menyambut sekolah tatap muka.

c. Promosi kesehatan dapat dilakukan oleh pemerintah maupun institusi pendidikan lainnya sebagai salah satu upaya promotif dan preventif dalam mencegah COVID-19 pada anak. 


\section{DAFTAR PUSTAKA}

Dewi, R. (2020). Tinjauan COVID-19 pada Anak: Infeksi hingga Terapi. Journal Of The Indonesian Medical Association, 70(8), 182-189.

Dewi, W. A. F. (2020). Dampak Covid-19 terhadap implementasi pembelajaran daring di Sekolah Dasar. Edukatif: Jurnal Ilmu Pendidikan, 2(1), 55-61.

Iftitah, S. (2020). Peran Orang Tua Dalam Mendampingi Anak Di Rumah Selama Pandemi Covid-19. JCE (Journal of Childhood Education) 4(2), 71-81

Kusumanita. (2020). Analisis Peran Orang Tua dalam Mendampingi Anak di Masa Pandemi covid-19. Jurnal Obsesi : Jurnal Pendidikan Anak Usia Dini 1(5), 241-256

Kemdikbud. (2021). Panduan Penyelenggaraan Pembelajaran di Masa Pandemi COVID-19. Kemendikbud, 2019, 1-58. https: //www.kemdikbud.go.id/main/blog/2020/06/buku- sakupanduan-pembelajaran-di-masa-pandemi-covid19

Kristiyanto, R. Y., Chandra, L., Hanjaya, H., Hakim, M. S., \& Nurputra, D. K. (2019). School reopening: Evidence-based recommendations during COVID-19 pandemic in Indonesia. Journal of Community Empowerment for Health, 4(1)

Lotfi, M., Hamblin, M. R., \& Rezaei, N. (2020). COVID-19: Transmission, prevention, and potential therapeutic opportunities. Clinica chimica acta.

Notoatmodjo, S. (2011). Promosi Kesehatan. Retrieved from http://r2kn.litbang.kemkes.go.id:8080/handle/123456789/77288

Pintek. (2020). Persiapan Anak Kembali ke Sekolah Setelah Masa Pandemi. Retrieved from https://pintek.id/blog/persiapan-anak-kembali-kesekolah/

UNICEF.(2020).Classroom Precautions During Covid19. Retrieved from https://www.unicef.org/coronavirus/teacher-tips-classroomprecautions-covid-19

UNICEF. (2020). COVID-19 Guide For Parents. Retrieved from https://www.unicef.org/parenting/coronavirus-covid-19-guideparents

UNICEF. (2020). Parenting Tips. Retrieved from https://www.unicef.org/coronavirus/covid-19-parenting-tips 